\title{
sciendo
}

\section{The cardiovascular complications of diabetes: a striking link through protein glycation}

\author{
MOUSA NUMAN AHMAD ${ }^{1}$, AMANI IBRAHIM FARAH ${ }^{1}$, TAREQ MUSBAH AL-QIRIM ${ }^{2}$
}

\footnotetext{
${ }^{1}$ Department of Nutrition and Food Technology, Human Nutrition and Dietetics, University of Jordan, Amman 11942, Jordan

${ }^{2}$ Faculty of Pharmacy, Al-Zaytoonah University of Jordan, Amman 11733, Jordan
}

\begin{abstract}
Diabetes mellitus is a predominant cause of mortality and morbidity worldwide. One of its serious health problems is cardiovascular complications. Advanced glycation end products (AGEs) are a group of heterogeneous toxic oxidant compounds that are formed after a non-enzymatic reaction between monosaccharides and free amino groups of proteins, compound lipids, and nucleic acids. AGE interacts with various types of cells through a receptor for AGE (RAGE). The interaction between AGE and RAGE is responsible for a cascade of inflammation, oxidative stress, and disruption of calcium homeostasis in cardiac cells of diabetic patients. There is striking evidence that the AGE/RAGE axis with its consequences on inflammation and oxidative stress plays a major role in the development of cardiovascular complications. Therefore, considering AGE as a therapeutic target with foreseeable results would be a wise direction for future research. Interestingly, several studies on nutraceutical, pharmaceutical, and natural products have begun to reveal promising therapeutic results, and this could lead to better health outcomes for many diabetic patients worldwide. This article discusses the current literature addressing the connection between protein glycation and diabetes cardiovascular complications and suggests future avenues of research.
\end{abstract}

Key words: AGEs, diabetes, cardiovascular disease, glycation, RAGE, sRAGE.

\section{HIGHLIGHTS}

- Protein glycation is a spontaneous chemical reaction of free reducing sugars with free amino groups of proteins forming toxic oxidant compounds known as advanced glycation end-products (AGEs).

- AGES are markedly associated with diabetes cardiovascular complications such as cardiomyopathy, heart failure, diastolic dysfunction, cardiac autonomic neuropathy, and peripheral artery disease that are the leading cause of diabetes mortality.

- AGEs act through specific receptors with quite complex and incomprehensible signaling cascades that can be considered markers of diabetes cardiovascular complications.

- AGEs and their receptors can be also considered a therapeutic target for some pharmaceutical, nutraceutical, and natural products.

\section{INTRODUCTION}

Diabetes mellitus is a group of metabolic disorders characterized by hyperglycemia associated with insufficient insulin secretion, defects in insulin action, or both [1]. Worldwide, it is estimated that around 436 million adults live with diabetes in 2019, and this number will reach 700 million people in 2045 [2]. The disease is also expected to have an annual incidence of $7 \%$ for type 2 and $1 \%$ for type 1 diabetes mellitus [3]. This alarmingly high prevalence of diabetes is known to affect both developed and rapidly developing countries, especially those with an aging population and lifestyle aberrations [3]. Diabetes results from an interplay between genetic and environmental factors; however, the dramatic increase in diabetes rates over the past few decades suggests an increasing role of the environmental factors [3]. Abnormal eating behaviors, physical inactivity, early life experiences, and dietary indiscretion are among the environmental factors that contribute to the development of the disease [2, 3]. Both micro and macrovascular complications are serious health implications most associated with diabetes mellitus. It is well appreciated that, in diabetes, cardiovascular complications are the leading cause of mortality and disability; in effect, these complications are responsible for $80 \%$ of diabetic mortality [4].

Although glycemic control is associated with a decrease in microvascular complications, it is often 
not associated with a corresponding reduction in cardiomyopathy complications [5]. This could indicate an alternative mechanism for the development of cardiovascular events along with the hyperglycemia. Some research has even suggested that cardiovascular complications can start from the prediabetes stage or at the same time as the stages of diabetes development [6]. Oxidative stress, inflammation, and nitric oxide depletion are all consequences of protein glycation, which are the main pathways contributing to the development of cardiovascular complications in diabetes [4]. Protein glycation is a spontaneous, non-enzymatic chemical reaction of free reducing sugars with free amino groups of proteins that lead to the formation of Amadori products [7]. These products undergo numerous irreversible rearrangement and dehydration reactions that lead to the generation of advanced glycation end-products (AGEs) [8]. Glycation reaction consists of two main parts, the first reversible part where proteins, lipids, and nucleic acids become a Schiff base after combination with reduced sugars, and a second irreversible part known as Millard reaction is a slow reaction that may require weeks to produce AGEs [9]. The second reaction is highly accelerated in the presence of hyperglycemia and tissue oxidative stress. Thus, excessive formation of AGEs and their accumulation in different tissues, have been linked with the long-term development of diabetic microvascular and macrovascular complications [8], an issue that has been extensively studied over the last three decades [5]. The objective of this article is to review the link between protein glycation and diabetes cardiovascular complications and suggests future research.

\section{LITERATURE SEARCH}

An up-to-date literature search was conducted on the link between protein glycation and diabetes cardiovascular complications. The search was limited to the most recent English publications covering the last 5 years (2015-2020). Relevant articles were principally identified through an online search of PubMed, Science Direct, and PsycINFO. Google Scholar and other databases were also used. The search process was performed using the following keywords or their combinations: AGEs, RAGE, sRAGE, cRAGE, esRAGE, nitric oxide, diabetes mellitus, cardiovascular disease and complications, protein glycation, Amadori products, Millard reaction, oxidative stress, antioxidants, and prooxidants. Included articles were mainly in vivo and in vitro original experimental, clinical, intervention, and cross-sectional researches in humans. Some researches in animals and review articles were also consulted. For further search accuracy, the reference lists of works were checked for additional publications from the major databases.

\section{ADVANCED GLYCATION END-PRODUCTS}

The AGEs are a group of heterogeneous toxic oxidant compounds that are formed after a spontaneous non-enzymatic reaction between amino groups of proteins, compound lipids, and nucleic acids with a monosaccharide such as glucose or fructose $[7,8]$. This reaction occurs both in vivo and in vitro, and it has a reversible Schiff base part that could be followed spontaneously by a slow irreversible Amadori reaction over a period ranging from days to several weeks $[10,11]$. Figure 1 presents the mechanism of glycation reaction cascade. The results of these reactions undertake additional condensation, dehydration, and rearrangement reactions to achieve the final forms of AGEs. Ne-carboxymethyl lysine, Pentosidine, $\mathrm{N} \varepsilon$-carboxyethyl lysine, methylglyoxal-derived hydroimidazolone 1, and cross-linked AGEs are common examples of AGEs compounds [4, 9].

The formation of AGEs occurs in intra- and extracellular proteins. Several studies have reported that AGEs accumulation is associated with protein cross-linking [11-13]. This cross-linking has great negative impacts on both collagen and elastin, particularly in diabetic patients [13]. Collagen affected by AGEs cross-linking is responsible for the loss of arterial elasticity, myocardial and vessel stiffness, decreased vessel lumen, increased thickness and fibrosis of the vessels, and eventually leading to atherosclerosis $[9,11,14]$. Elastin affected by AGE cross-linking is prone to lose its function, and this is one of the major contributing factors for essential hypertension in diabetic patients. Furthermore, damaged proteins by AGEs cross-linking has low clearance potential, clear loss of functionality, and altered enzymatic activities $[11,13]$.

\section{RECEPTOR AXIS}

The AGEs interact with diverse types of cells through a receptor for AGE (RAGE). RAGE receptors belong to the immunoglobulin superfamily. The interaction between AGE and RAGE is responsible for a cascade of inflammation, oxidative stress, and disturbances in calcium homeostasis in cardiac cells of diabetic patients $[9,15]$. Figure 2 
shows the advanced glycation-end product pathways for the development of diabetes cardiovascular complications. Furthermore, AGE-RAGE activation leads to an acceleration in AGE production; thus, a vicious cycle of intracellular toxic interactions will progress. AGE-RAGE axis depletes nitric oxide is one of the major protective factors against atherosclerosis $[9,15]$. The depletion of nitric oxide occurs through several well-known mechanisms such as oxidative stress and the formation of dimethylarginine, an endogenous inhibitor of nitric oxide in endothelial cells $[15,16]$.

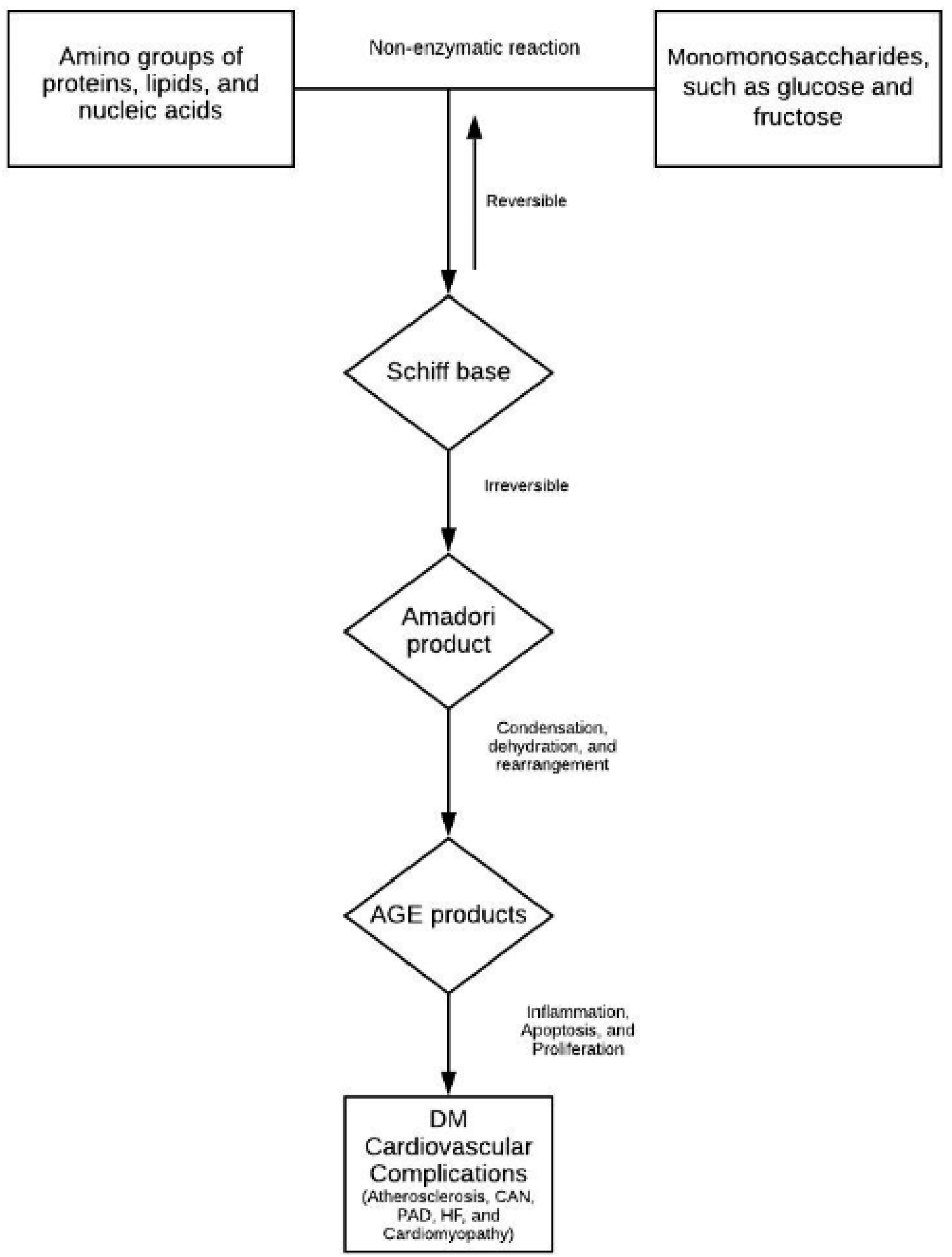

Figure 1. Mechanism of glycation reaction cascade. AGE: Advanced glycation-end products; DM: Diabetes mellitus; HF: Heart failure; CAN: Cardiac autonomic neuropathy; PAD: Peripheral artery disease. 


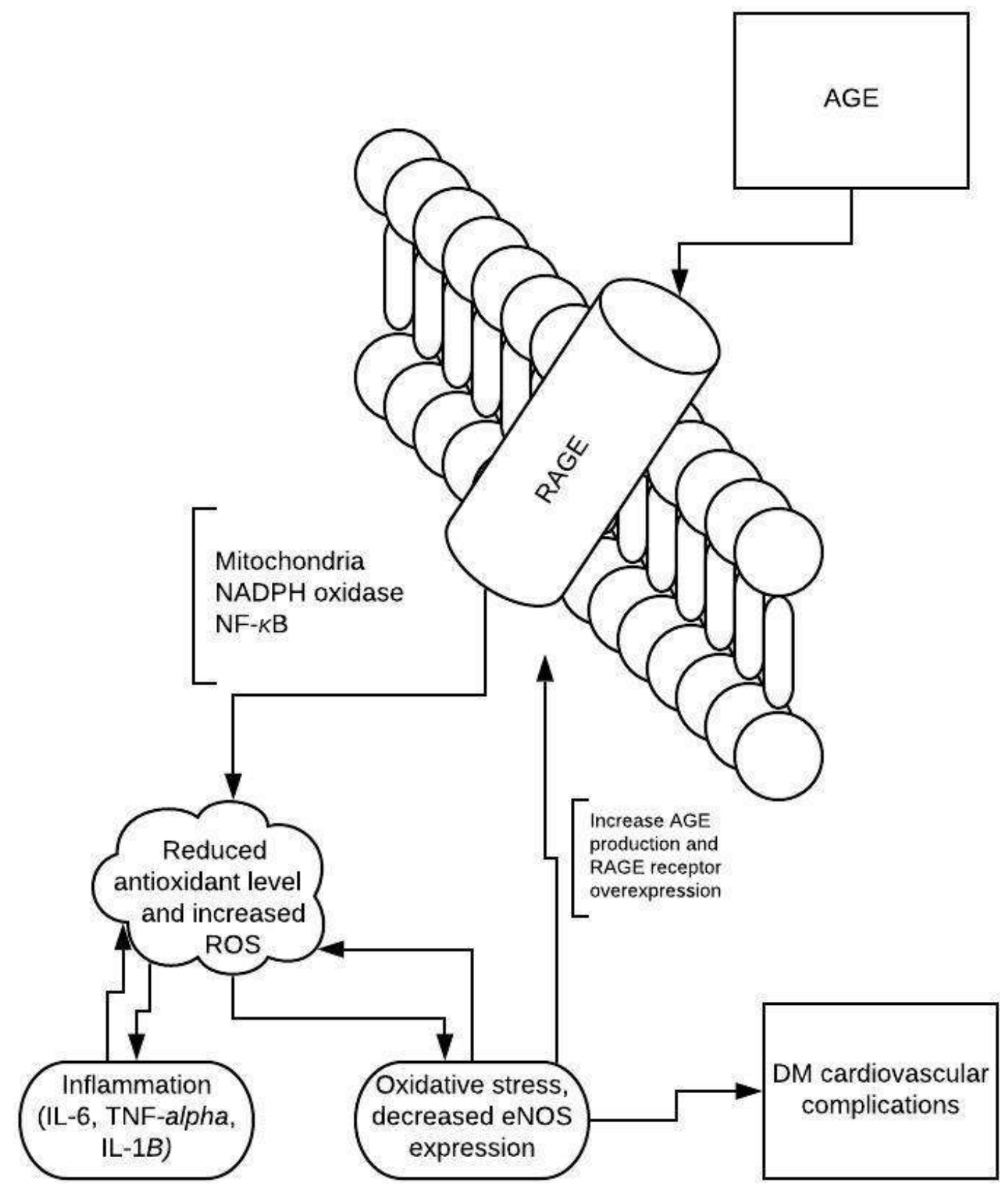

Figure 2. Advanced glycation-end product pathways for the development of diabetes cardiovascular complications. AGE: Advanced glycation end-product; DM: Diabetes mellitus; ROS: Reactive oxygen species; RAGE: Receptor for AGE; eNOS: Endothelial nitric oxide synthase; TNF-alpha: Tumor necrosis factor-alpha; IL-6: Interleukeine-6; IL-1ß: Interleukeine-1ß.

Moreover, the AGE-RAGE axis simulates the development of plaques by overturning cholesterol efflux from macrophages and simulating the rupture of plaques in diabetic patients through pathological angiogenesis $[10,15]$. Furthermore, the AGE-RAGE axis suppresses endothelial cells repair and stimulates $\mathrm{NF}-\kappa \mathrm{B}$ that leads to endothelial inflammation [10, 15]. One therapeutic potential for the suppression of the AGE-RAGE axis is by getting benefit from what is called metabolic memory through active control of diabetes mellitus upon diagnosis to attenuate some of the AGE-RAGE axis risks [17].

\section{POSSIBLE MOLECULAR MECHANISMS}

The RAGE receptors have intracellular, transmembrane, and extracellular components, whereas the soluble receptor for AGE (sRAGE) has only the extracellular component of RAGE [4]. The sRAGE binds with AGE and other RAGEligands without inducing the intracellular cascade; thus, it competes with the AGE-RAGE axis [6]. It has been reported that sRAGE has a negative crosssectional correlation with cardiovascular complications in diabetic, prediabetes, and non-diabetic individuals 
$[4,6,18]$. Patients with a lower number of sRAGE have a higher cardiovascular mortality rate [19]. The higher rate of sRAGE is associated with less incidence of arterial fibrillation after catheter ablation of diabetic patients. A recent study found that sRAGE is responsible for the inhibition of some of the inflammatory factors yielding a reduction in endothelial cell dysfunction [4].

The potential negative effects of AGEs can be caused by three mechanisms: modifications of extracellular and intracellular proteins and signaling cascade mechanism [20]. Extracellular protein modifications affect protein function and structure and are associated with pro-inflammatory responses [21]. The main extracellular proteins affected are long lifespan proteins such as collagen and elastin. This type of modification can be detected in lenses, joints, muscles, bones, cardiomyocytes, and skin [20]. Collagen glycation leads to proteolytic resistant and protein cross-linking that affects myocardial and vascular stiffness. Likewise, the glycation of elastin leads to the migration of endothelial cells and impaired adhesion. Protein cross-linking is a direct effect of extracellular protein glycation [20]. Several studies have linked this cross-linking with cardiac disease, nitric oxide depletion, and eventually impaired vasodilatation [20-22].

Another direct effect of this non-enzymatic reaction is its glycation ability on low-density lipoproteins [22]. This may lead to a decrease in the interaction of low-density lipoproteins with uptake receptors reducing their engulfment by macrophages and monocytes, thereby accelerating the development of foam cells [22]. Besides, AGEs increase the chances of thrombogenesis by stimulating the platelet sensitivity to aggregating factors and reducing thrombolysis by alternating the heparin cofactor-2 and annexin-2. Some studies have revealed a marked association between extracellular accumulation of AGE and the development of atherosclerosis [23, 24].

Furthermore, the intracellular negative effects of AGEs are by the modification of intracellular proteins [20]. Accumulation of AGEs on the mitochondrial proteins leads to a reduction in adenosine triphosphate synthesis and an increase in the production of reactive oxygen species and superoxides [25]. This accumulation also leads to the development of unfolded proteins in the endoplasmic reticulum. These defective proteins could induce apoptosis. Moreover, AGEs inhibit glutathione reductase and glutathione peroxidase activities, and this inhibition is responsible for the low production of antioxidants in the body $[10,20]$. Further, AGEs intracellular effects are associated with disturbed calcium function in the myocardial cells, which is a causative factor for contractility impairment and systolic heart failure [10, 20, 27].

The third mechanism for AGE's negative effects is through the induction of several signaling cascades [20]. These signals mediate the generation of pro-inflammatory factors, reactive oxygen species, and thrombogenesis. Inflammatory factors enhance the development of extra AGEs through the AGE/ RAGE axis leading to a vicious cycle of negative consequences on several issues such as tumor formation, amyloidosis, and neurodegeneration [20, 27]. Another signaling cascade affected by AGE accumulation is the activation of the Janus kinase/ signal transducer and activator of transcription pathway (Jak/Stat) that is associated with inflammatory, cell apoptosis, and tumor formation [28, 29]. Moreover, AGE/RAGE activation leads to a depletion in nitric oxide levels. The latter not only works as a vasodilator, but it also has an important role in the prevention of thrombosis. Nitric oxide is an antioxidant and an anti-proliferative agent [30]. Reduction of nitric oxide could induce the production of reactive oxygen and nitrogen species. The activation of oxidative stress eventually leads to apoptosis, cell calcification in vessel walls, and loss of elasticity $[29,30]$. Furthermore, AGE/ RAGE signaling cascade activates nicotinamide adenine dinucleotide phosphate through the overexpression of $N F \kappa \beta[8,20]$. This leads to increased production of reactive oxygen species and stimulation of another positive feedback cycle by inducing $N F \kappa \beta$. It has been reported that the NF $\kappa \beta$ simulation cycle through mitogen-activated protein kinase (MAP kinase) activation is responsible for additional production of pro-inflammatory cytokines, interleukins, tumor necrosis factor- $\alpha$, intercellular adhesion molecule-1, vascular cell adhesion protein- 1 , and endothelin-1 $[8,20]$.

\section{OTHER RECEPTORS}

It is important to address that binding of AGEs to RAGE receptors is responsible for the aboveexplained signaling cascades. However, AGEs are known to bind to several other receptors [20]. In general, these receptors can be divided into two main types according to their interaction with AGEs [20]. The first type is receptors that have antagonizing effects for AGEs, and the second type is receptors that have agonizing effects for AGEs. The sRAGE 
receptors and AGE-R1 receptors are two known receptors that antagonize the effects of RAGE. It has been reported that underexpression of AGE-R1 receptors is associated with diabetes mellitus complications and the induction of inflammation [24-26]. The sRAGE receptors include different subtypes: the endogenous secreted RAGE (esRAGE) and cleave type soluble RAGE (cRAGE) are the main ones [25-28]. Metalloproteinases can produce cRAGE from cleaving the RAGE receptor that is anchored in the cell membrane [31]. Therefore, metalloproteinases indirectly antagonize AGEs effects [32]. The sRAGE are receptors that lack a membranespanning and lack intracellular domain, yet they can bind with AGE with different binding affinities and without initiating any signaling cascades [20]. Other examples of receptors that antagonize AGE effects are galectin-3, 80-KH phosphoprotein, oligosaccharyltransferase-48, and a cluster of differentiation 36 receptors [33]. On the other hand, RAGE is the best example of receptors that agonize the effects of AGEs [20]. RAGE consists of three domains: the extracellular domain composed of v-type and two c-type subdomains, intramembrane domain, and intracellular domain. Figure 1 illustrates the advanced glycation end-product receptors and their proposed mechanisms. RAGE receptors have been identified in several tissues and cells, such as endothelial and myocardial cells, nerve cells, and macrophages [20].

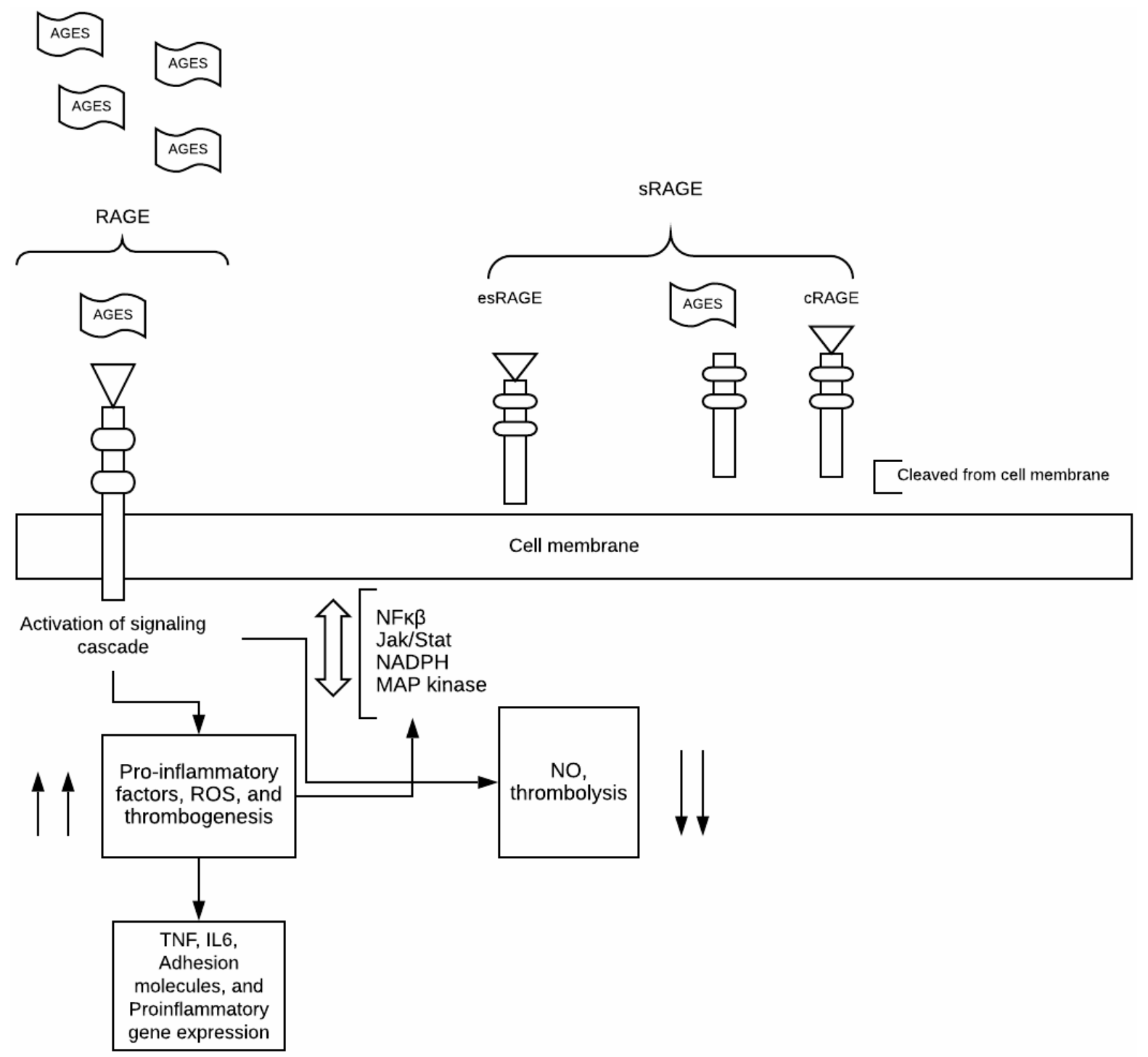

Figure 3. Illustration for advanced glycation end-product receptors and their proposed mechanisms.

AGE: Advanced glycation end-products; ROS: Reactive oxygen species; eNO: Endothelial nitric Oxide; RAGE: Receptor for AGE; esRAGE: endogenous secreted RAGE; sRAGE: Soluble RAGE; cRAGE: cleave type RAGE; TNF: Tumor necrosis factor; IL-6: Interleukeine-6; Jak/Stat: Janus kinase/ signal transducer and activator of transcription pathway; MAP kinase: Mitogen-activated protein kinase. 


\section{CONNECTION WITH DIABETES CARDIOVASCULAR COMPLICATIONS}

Since cardiovascular complications are the predominant cause of diabetes mortality, it is important to investigate the mechanism of development and etiological factors for these complications. A wide range of these atherosclerotic complications is associated with diabetes mellitus [4]. These include heart failure, cardiomyopathy, diastolic dysfunction, vessel permeability dysfunction, increase thickness of intima-media, and barrier dysfunction [9, 33-35]. Diabetic patients have 2 to 5 times more risk to develop heart failure with poor prognosis and early onset of this complication [14].

Accumulation of AGEs in diabetes mellitus damage cardiomyocytes by multiple mechanisms; these include altering protein function, activating the AGE-RAGE axis, inducing inflammatory factor and reactive oxygen species formation, and changing the extracellular matrix and affecting its function [35]. Some research has revealed that AGEs affect calcium signaling pathways and directly affect ligandreceptor interactions [33-35]. However, glycemic control in other models did not achieve the control level of AGEs; thus, was not effective in preventing cardiomyopathies [36]. AGEs modulate myosin and actin, leading to depressed calcium activity consequently, actin and myosin interact with thinfilament regulatory proteins, contributing to one of the major risk factors for heart failure in patients with diabetes [37].

Analysis of the results of the CORDIOPREV clinical trial has shown that high levels of methylglyoxal, an AGE compound, are associated with narrowing of intima-media thickness of common carotid arteries [11]. This narrowing is an early sign of atherosclerosis and is closely linked to vascular damage. The negative inflammatory and protein cross-linking effects of AGEs could explain this damage to the common carotid artery [11]. AGEs also contribute to endothelial dysfunction by inducing vasoconstriction through endothelin-1 and reducing vasodilatation via depletion of nitric oxide $[11,38,39]$. Besides, hyperglycemia mediated AGEs excessive accumulation leads to extracellular matrix damage and a decline in several enzymatic activities [40]. Many inflammatory factors and oxidative damage are also strongly linked to AGE-RAGE activation. The AGEs stimulation of nuclear factor erythroid 2-related factor 2 and AGE triggering of nuclear factor kappa B are common pathways contributing to the development of diabetes cardiovascular complications, including vascular dysfunction [33,
41]. The intima-media thickness of common carotid arteries in the CORDIOPREV study could be explained by excessive accumulation of AGE that leads to the development of collagen stiffness and inflexible fibrin network [11,23].

\section{POSSIBLE THERAPEUTIC TARGETS}

The AGEs are produced internally by normal physiological mechanisms, but their main source is externally through food and tobacco consumption [42]. About 7\% of all consumed AGEs remain in the body [9]. Certain types of foods, such as cooked or processed foods, contain high concentrations of AGEs [42]. Reducing the intake of AGE-rich foods in diabetic patients produces positive effects on nitric oxide, C-reactive protein, plasminogen activator inhibitor 1, AGEs, total cholesterol, and oxidative stress $[10,42]$.

Lifestyle modifications, smoking cessation, and control of body weight, dyslipidemia, and hyperglycemia remain the main therapeutic approaches to prevent cardiovascular complications in diabetes mellitus [43]. It is worth mentioning that glycemic control does not affect the results of heart failure hospitalization [44]. The therapeutic targets for AGEs are to block their signaling cascades, increase their degradation activity, impeding their formation, and genetic therapy is recently explored $[8,20]$. Even though several in vitro experiments have shown promising results in this context; sometimes these results are not reflected in human studies, and many therapeutic interventions showed serious side effects in clinical trials, or unfortunately, some are terminated prematurely due to financial constraints [13]. Although the discussion of therapeutic approaches to control or manage cardiovascular complications is beyond the scope of this review, a summary of recent researches of current or promising pharmaceutical, nutraceutical, and natural agents, that showed striking results on prevention or management of diabetes cardiovascular complications through controlling the levels of AGE and/or oxidative stress is presented in Table 1 [51-59].

\section{CURRENT LIMITATIONS}

One of the main limitations of AGE studies is the lack of consensus among the scientific communities about the ideal method for AGE quantification $[45,46]$. Several measurement methods have been proposed and tested by researchers 
in the last several decades. These include the determination of serum and urine AGE, skin fluorescent assay, and tissue level analysis. However, the results of these different methods were inconsistent and sometimes yielded contradicted results [7, 45-48].

Table 1

Pharmaceutical, nutraceutical, and natural interventions against advanced glycation end-products

\begin{tabular}{|c|c|c|c|}
\hline Type of agent/study & Therapeutic agent & Mechanism of AGE modulation & Reference \\
\hline Natural/animal study & Sulforaphane & $\begin{array}{l}\text { Reduction in reactive oxygen species production through activation } \\
\text { of Nrf2 factor that leads to a better cardiac modeling }\end{array}$ & [51] \\
\hline $\begin{array}{l}\text { Nutraceutical/animal } \\
\text { study }\end{array}$ & Coenzyme $\mathrm{Q}_{10}$ & $\begin{array}{l}\text { Reduction in oxidative stress through cardiac remodeling that leads } \\
\text { to vasodilatation and reduction in inflammation and hypertrophy }\end{array}$ & {$[52]$} \\
\hline $\begin{array}{l}\text { Pharmaceutical/animal } \\
\text { study }\end{array}$ & $\begin{array}{l}\text { Glucagon-like } \\
\text { peptide-1 }\end{array}$ & $\begin{array}{c}\text { Activation of glucagon-like peptide-1 receptor/cAMP/PKA } \\
\text { pathway and inactivation of RAGE/Rho/ROCK pathway that lead } \\
\text { to a healthier endothelial barrier }\end{array}$ & [53] \\
\hline $\begin{array}{l}\text { Genetic treatment/animal } \\
\text { study }\end{array}$ & DNA-aptamers & $\begin{array}{l}\text { Attenuation of AGE/RAGE mediated oxidative stress and } \\
\text { suppression of adipocyte remodeling }\end{array}$ & {$[54]$} \\
\hline $\begin{array}{l}\text { Pharmaceutical/human } \\
\text { study }\end{array}$ & $\begin{array}{l}\text { Chelation therapy } \\
\text { (TACT) }\end{array}$ & $\begin{array}{l}\text { Reduction in metal-catalyzed oxidation pathway that could } \\
\text { accelerate AGEs generation. Thus, the reduction of all-cause } \\
\text { myocardial infarction, stroke, coronary revascularization, and } \\
\text { hospitalization for angina in the study participants }\end{array}$ & {$[55]$} \\
\hline $\begin{array}{l}\text { Pharmaceutical/animal } \\
\text { study }\end{array}$ & Irbesartan & $\begin{array}{l}\text { Down-regulation of matrix metallo-proteinases pathway and } \\
\text { suppression of AGE/RAGE signaling cascade that reduce } \\
\text { myocardial fibrosis }\end{array}$ & {$[56]$} \\
\hline $\begin{array}{l}\text { Pharmaceutical/in vitro } \\
\text { study }\end{array}$ & Metformin & $\begin{array}{c}\text { Inactivation of AGEs-mediated inflammatory impacts via activation } \\
\text { of AMPK and inhibition of RAGE/NF } \kappa \text { B pathway that might lead } \\
\text { to improving diabetic atherosclerosis }\end{array}$ & {$[57]$} \\
\hline $\begin{array}{l}\text { Pharmaceutical/animal } \\
\text { study }\end{array}$ & Pioglitazone & $\begin{array}{l}\text { Reduction in RAGE signaling cascade and triggering PPAR- } \gamma \\
\text { protein expression in carotid plaque that improves the } \\
\text { atherosclerosis results }\end{array}$ & [58] \\
\hline Natural/human study & Alpha-lipoic acid & $\begin{array}{l}\text { Reduction in C-reactive protein, IL- } 6 \text {, and TNF- } \alpha \text {; thus, reducing } \\
\text { the activity of systemic inflammation as a predictor of cardiac } \\
\text { complication in patients with type } 2 \text { diabetes }\end{array}$ & [59] \\
\hline
\end{tabular}

Despite having strong evidence from several clinical studies about the association between AGEs and cardiovascular complications of diabetes mellitus and other chronic diseases, yet there are some reports with contradictory results [45-48]. Recently, some studies failed to identify AGEs, AGE/RAGE, or AGE/sRAGE levels as predictors or markers for diabetes cardiovascular complications [6, 49]. Prasad and colleagues [50] reported that AGEs are not correlated with diabetes nor with renal complications. However, AGEs are a heterogeneous group of molecules some of these have fluorescent characteristics, while others do not, so it is expected to find some variations in measurement methodology [49]. Therefore, not having a standard method for AGEs quantification remains a serious issue in most research.

The AGEs are a very heterogeneous group of products; thus, it is difficult to determine which exact product has the main activity to be targeted by therapeutic agents [49]. AGEs have also different receptor affinity and most probably, vary significantly in their physiological activity $[49,50]$. Furthermore, the non-enzymatic activities that produce AGEs and their signaling cascades are quite complex and not fully understood. Therefore, it is challenging to identify which step or steps that could contribute to maximizing the effect of AGEs and should be chosen as a therapeutic target [8]. Consequently, these inconsistencies must be considered as major challenges for future research.

\section{CONCLUSIONS}

Taken together, diabetic patients can develop a group of serious cardiovascular complications with poor outcomes. There is striking evidence that the AGE/RAGE axis with its consequences on inflammation and oxidative stress, plays a vital role in the development of these complications. Therefore, considering AGEs as a therapeutic target with 
foreseeable results would be a wise direction for future research. Fortunately, many studies on pharmaceutical, nutraceutical, and natural products started to reveal promising therapeutic results, and this could lead to better health outcomes for millions of diabetic patients around the globe.

Diabetul zaharat este o cauză importantă de mortalitate şi morbiditate în intreaga lume. Una dintre cele mai importante complicații ale sale este reprezentată de bolile cardiovasculare. Compuşii de glicare (AGEs) reprezintă o clasă de compuşi toxici heterogeni care se formează după o reacţie non-enzimatică dintre monozaharide şi grupările amino libere ale aminoacizilor, ale lipidelor sau ale acizilor nucleici. AGE interacţionează cu o varietate de celule prin intermediul receptorilor pentru $A G E$ (RAGE). Interacţiunea dintre $A G E$ şi RAGE este responsabilă pentru o cascadă inflamatorie a stresului oxidativ, precum şi a dezechilibrului homeostaziei calciului intracelular la pacienţii diabetici. Sunt din ce în ce mai multe dovezi că axa AGE/RAGE împreună cu consecinţele sale joacă un rol important în dezvoltarea complicațiilor cardiovasculare. Astfel putem considera AGE ca o potenţială ţintă terapeutică pentru studii viitoare. Mai multe studii au arătat că anumiţi produşi farmaceutici sau nutriţionali pot avea un rol terapeutic important, ceea ce ar putea duce la un prognostic mai bun al acestor pacienți. Recenzia de faţă trece în revistă legătura dintre $A G E$, diabet şi complicațiile cardiovasculare.

Correspondence to: Prof. Mousa Numan Ahmad, Department of Nutrition and Food Technology, Human Nutrition and Dietetics, University of Jordan, Amman 11942 Jordan

Fax +962-6-530-0806

Telephone $+962772609701 ;+962797509543$

E-mail: mosnuman@ju.edu.jo; mousanuman@gmail.ccom

Acknowledgments: The authors would like to thank the University of Jordan, Amman, Jordan, and Al-Zaytoonah University of Jordan, Amman, Jordan.

Conflict of interest disclosure: The authors declare that there are no conflicts of interest.

\section{REFERENCES}

1. PUNTHAKEE Z., GOLDENBERG R., KATZ P. Definition, classification and diagnosis of diabetes, prediabetes and metabolic syndrome. Can J Diabetes. 2018; 42(1):S10-5.

2. International Diabetes Federation. IDF diabetes atlas. 9th ed. International Diabetes Federation, Brussels, Belgium, 2019.

3. XU G., LIU B., SUN Y., DU Y., SNETSELAAR LG., HU FB., et al. Prevalence of diagnosed type 1 and type 2 diabetes among US adults in 2016 and 2017: population- based study. BMJ. 2018; 362:k1497.

4. YANG P., FENG J., PENG Q., LIU X., FAN Z. Advanced glycation end products: potential mechanism and therapeutic target in cardiovascular complications under diabetes. Oxid Med Cell Longev. 2019; 2019:9570616.

5. SCHALKWIJK CG., STEHOUWER C. Methylglyoxal, a highly reactive dicarbonyl compound, in diabetes, its vascular complications, and other age-related diseases. Physiol Rev. 2020; 100(1):407-61.

6. GATEVA AT., ASSYOV YS., TSAKOVA AD., KAMENOV ZA. Serum AGEs and sRAGE levels are not related to vascular complications in patients with prediabetes. Diabetes Metab Syndr. 2019; 13(2):1005-10.

7. KIM CS., PARK S., KIM J. The role of glycation in the pathogenesis of aging and its prevention through herbal products and physical exercise. J Exerc Nutr Biochem. 2017; 21(3):55-61.

8. CHAUDHURI J., BAINS Y., GUHA S., KAHN A., HALL D., BOSE N., et al. The role of advanced glycation end products in aging and metabolic diseases: bridging association and causality. Cell Metab. 2018; 28(3):337-52.

9. YAMAGISHI S. Role of advanced glycation endproduct (AGE)-receptor for advanced glycation endproduct (RAGE) axis in cardiovascular disease and its therapeutic intervention. Circ J. 2019; 83(9):1822-8.

10. CEPAS V., COLLINO M., MAYO JC., SAINZ RM. Redox signaling and advanced glycation endproducts (AGEs) in dietrelated diseases. Antioxidants. 2020; 9(2):142.

11. DE LA CRUZ-ARES S., CARDELO MP., GUTIÉRREZ-MARISCAL FM., TORRES-PEÑA JD., GARCÍA-RIOS A., KATSIKI N., et al. Endothelial dysfunction and advanced glycation end products in patients with newly diagnosed versus established diabetes: from the CORDIOPREV study. Nutrients. 2020; 12(1):238. 
12. ROJAS A., AÑAZCO C., GONZÁLEZ I., ARAYA P. Extracellular matrix glycation and receptor for advanced glycation endproducts activation: a missing piece in the puzzle of the association between diabetes and cancer. Carcinogenesis. 2018; 39(4):515-21.

13. TOPRAK C., YIGITASLAN S. Alagebrium and complications of diabetes mellitus. Eurasian J Med. 2019; 51(3):285-92.

14. BORGHETTI G., VON LEWINSKI D., EATON DM., SOURIJ H., HOUSER SR., WALLNER M. Diabetic cardiomyopathy: current and future therapies. beyond glycemic control. Front Physiol. 2018; 9:1514.

15. YAMAGISHI S., MATSUI T. Role of hyperglycemia-induced advanced glycation end-product (AGE) accumulation in atherosclerosis. Ann Vasc Dis. 2018; 11(3):253-8.

16. CHANG GJ., YEH YH., CHEN WJ., KO YS., PANG JS., LEE HY. Inhibition of advanced glycation end products formation attenuates cardiac electrical and mechanical remodeling and vulnerability to tachyarrhythmias in diabetic rats. $\mathrm{J}$ Pharmacol Exp Ther. 2019; 368(1):66-78.

17. PERRONE A., GIOVINO A., BENNY J., MARTINELLI F. Advanced glycation end products (AGEs): biochemistry, signaling, analytical methods, and epigenetic effects. Oxid Med Cell Longev. 2020; 2020:3818196.

18. DI PINO A., URBANO F., SCICALI R., DI MAURO S., FILIPPELLO A., SCAMPORRINO A., et al. 1 h postload glycemia is associated with low endogenous secretory receptor for advanced glycation end-product levels and early markers of cardiovascular disease. Cells. 2019; 8(8):910.

19. EGAÑA-GORROÑO L., LÓPEZ-DÍEZ R., YEPURI G., RAMIREZ LS., REVERDATTO S., GUGGER PF., et al. Receptor for advanced glycation end products (RAGE) and mechanisms and therapeutic opportunities in diabetes and cardiovascular disease: insights from human subjects and animal models. Front Cardiovasc Med. 2020; 7:37.

20. FISHMAN SL., SONMEZ H., BASMAN C., SINGH V., PORETSKY L. The role of advanced glycation end-products in the development of coronary artery disease in patients with and without diabetes mellitus: a review. Mol Med. 2018; $24(1): 59$.

21. ROWAN S., BEJARANO E., TAYLOR A. Mechanistic targeting of advanced glycation end-products in age-related diseases. BBA-Mol Basis Dis. 2018; 1864(12):3631-43.

22. XU L., WANG YR., LI PC., FENG B. Advanced glycation end products increase lipids accumulation in macrophages through upregulation of receptor of advanced glycation end products: increasing uptake, esterification and decreasing efflux of cholesterol. Lipids Health Dis. 2016; 15(1):161.

23. SAREMI A., HOWELL S., SCHWENKE DC., BAHN G., BEISSWENGER PJ., REAVEN PD., et al. Advanced glycation end products, oxidation products, and the extent of atherosclerosis during the VA diabetes trial and follow-up study. Diabetes care. 2017; 40(4):591-8.

24. KOSMOPOULOS M., DREKOLIAS D., ZAVRAS PD., PIPERI C., PAPAVASSILIOU AG. Impact of advanced glycation end products (AGEs) signaling in coronary artery disease. BBA-Mol Basis Dis. 2019; 1865(3):611-19.

25. STEFANO GB., CHALLENGER S., KREAM RM. Hyperglycemia-associated alterations in cellular signaling and dysregulated mitochondrial bioenergetics in human metabolic disorders. Eur J Nutr. 2016; 55(8):2339-45.

26. LIU Q., HUA B., SU W., DI B., YU S., GAO S., et al. AGEs impair Kv channel-mediated vasodilation of coronary arteries by activating the $N F-\kappa B$ signaling pathway in ZDF rats. Biomed Pharmacother. 2019; 120:109527.

27. BONGARZONE S., SAVICKAS V., LUZI F., GEE AD. Targeting the receptor for advanced glycation endproducts (RAGE): a medicinal chemistry perspective. J Med Chem. 2017; 60(17):7213-32.

28. SUN M., LI Y., BU W., ZHAO J., ZHU J., GU L., et al. DJC suppresses advanced glycation end products-induced JAK-STAT signaling and ROS in mesangial cells. Evid-Based Compl Alt. 2017; 2017:2942830.

29. YU J., WU H., LIU ZY., ZHU Q., SHAN C., ZHANG KQ. Advanced glycation end products induce the apoptosis of and inflammation in mouse podocytes through CXCL9-mediated JAK2/STAT3 pathway activation. Int J Mol Med. 2017; 40(4): 1185-93.

30. REN X., REN L., WEI Q., SHAO H., CHEN L., LIU N. Advanced glycation end-products decreases expression of endothelial nitric oxide synthase through oxidative stress in human coronary artery endothelial cells. Cardiovasc Diabetol. $2017 ; \mathbf{1 6}(1): 52$.

31. BRALEY A., KWAK T., JULES J., HARJA E., LANDGRAF R., HUDSON BI. Regulation of receptor for advanced glycation end products (RAGE) ectodomain shedding and its role in cell function. J Biol Chem. 2016; 291(23):12057-73.

32. CRASCÌ L., LAURO MR., PUGLISI G., PANICO A. Natural antioxidant polyphenols on inflammation management: Antiglycation activity vs metalloproteinases inhibition. Crit Rev Food Sci Nutr. 2018; 58(6):893-904.

33. KAUR R., KAUR M., SINGH J. Endothelial dysfunction and platelet hyperactivity in type 2 diabetes mellitus: molecular insights and therapeutic strategies. Cardiovasc Diabetol. 2018; 17(1):121.

34. ROUMELIOTIS A., ROUMELIOTIS S., PANAGOUTSOS S., THEODORIDIS M., ARGYRIOU C., TAVRIDOU A., et al. Carotid intima-media thickness is an independent predictor of all-cause mortality and cardiovascular morbidity in patients with diabetes mellitus type 2 and chronic kidney disease. Ren Fail. 2019; 41(1):131-8.

35. JOUBERT M., MANRIQUE A., CARIOU B., PRIEUR X. Diabetes-related cardiomyopathy: the sweet story of glucose overload from epidemiology to cellular pathways. Diabetes Metab. 2019; 45(3):238-47.

36. HABIBI J., AROOR AR., SOWERS JR., JIA G., HAYDEN MR., GARRO M., et al. Sodium glucose transporter 2 (SGLT2) inhibition with empagliflozin improves cardiac diastolic function in a female rodent model of diabetes. Cardiovasc Diabetol. 2017; 16(1):9.

37. AHMAD MN., FARAH AI., AL-QIRIN TM. Examining the role of alpha-lipoic acid and epigallocatechin-c-gallate in inhibiting sugar-induced myoglobin glycation: scientific gaps in current knowledge? Nat Sci. 2020; 18(6):17-25.

38. LILJE C., CRONAN JC., SCHWARTZENBURG EJ., OWERS EM., CLESI P., GOMEZ R., et al. Intima-media thickness at different arterial segments in pediatric type 1 diabetes patients and its relationship with advanced glycation end products. Pediatr Diabetes. 2018; 19(3):450-6.

39. MATSUMOTO T., KOJIMA M., TAKAYANAGI K., KATOME T., TAGUCHI K., KOBAYASHI T. Amplification of the COX/TXS/TP receptor pathway enhances uridine diphosphate-induced contraction by advanced glycation end products in rat carotid arteries. Pflug Arch Eur J phy. 2019; 471(11-12):1505-17. 
40. RAJARAMAN B., RAMADAS N., KRISHNASAMY S., RAVI V., PATHAK A., DEVASENA CS., et al. Hyperglycaemia cause vascular inflammation through advanced glycation end products/early growth response-1 axis in gestational diabetes mellitus. Mol Cell Biochem. 2019; 456(1-2):179-90.

41. PETRIE JR., GUZIK TJ., TOUYZ RM. Diabetes, hypertension, and cardiovascular disease: clinical insights and vascular mechanisms. Can J Cardiol. 2018; 34(5):575-84.

42. CLARKE RE., DORDEVIC AL., TAN SM., RYAN L., COUGHLAN MT. Dietary advanced glycation end products and risk factors for chronic disease: a systematic review of randomized controlled trials. Nutrients. 2016; 8(3):125.

43. MAKIN V., LANSANG MC. Diabetes management: beyond hemoglobin $A_{l c}$. Cleve Clin J Med. 2019; 86(9):595-600.

44. REAVEN PD., EMANUELE NV., WIITALA WL., BAHN GD., REDA DJ., MCCARREN M., et al. Intensive glucose control in patients with type 2 diabetes - 15-year follow-up. N Engl J Med. 2019; 380(23):2215-24.

45. KLONT F., HADDERINGH M., HORVATOVICH P., TEN HACKEN N., BISCHOFF R. Affimers as an alternative to antibodies in an affinity LC-MS assay for quantification of the soluble receptor of advanced glycation end-products (SRAGE) in human serum. J Proteome Res. 2018; 17(8):2892-99.

46. KLONT F., POUWELS SD., HERMANS J., VAN DE MERBEL NC., HORVATOVICH P., TENHACKEN N., et al. A fully validated liquid chromatography-mass spectrometry method for the quantification of the soluble receptor of advanced glycation end-products (sRAGE) in serum using immunopurification in a 96-well plate format. Talanta. 2018; 182:414-21.

47. BANARJEE R., SHARMA A., BAI S., DESHMUKH A., KULKARNI M. Proteomic study of endothelial dysfunction induced by AGEs and its possible role in diabetic cardiovascular complications. J Proteom. 2018; 187:69-79.

48. Qiu H., Jin L., Chen J., Shi M., Shi F., Wang M., et al. Comprehensive glycomic analysis reveals that human serum albumin glycation specifically affects the pharmacokinetics and efficacy of different anticoagulant drugs in diabetes. Diabetes. 2020; 69(4):760-70.

49. CAVERO-REDONDO I., SORIANO-CANO A., ÁlVAREZ-BUENO C., CUNHA PG., MARTÍNEZ-HORTELANO JA., GARRIDO-MIGUEL M., et al. Skin autofluorescence-indicated advanced glycation end products as predictors of cardiovascular and all-cause mortality in high-risk subjects: a systematic review and meta-analysis. J Am Heart Assoc. 2018; 7(18):e009833.

50. PRASAD C., DAVIS KE., IMRHAN V., JUMA S., VIJAYAGOPAL P. Advanced glycation end products and risks for chronic diseases: intervening through lifestyle modification. Am J Lifestyle Med. 2019; 13(4):384-404.

51. WANG J., WANG S., WANG W., CHEN J., ZHANG Z., ZHENG Q., et al. Protection against diabetic cardiomyopathy is achieved using a combination of sulforaphane and zinc in type 1 diabetic OVE26 mice. J Cell Mol Med. 2019; 23(9):6319-30.

52. ULLA A., MOHAMED MK., SIKDER B., RAHMAN AT., SUMI FA., HOSSAIN M., et al. Coenzyme Q10 prevents oxidative stress and fibrosis in isoprenaline induced cardiac remodeling in aged rats. BMC Pharmacol Toxico. 2017; 18:29.

53. TANG ST., TANG HQ., SU H., WANG Y., ZHOU Q., ZHANG Q., et al. Glucagon-like peptide-1 attenuates endothelial barrier injury in diabetes via cAMP/PKA mediated down-regulation of MLC phosphorylation. Biomed Pharmacother. 2019; 113:108667.

54. OJIMA A., MATSUI T., NAKAMURA N., HIGASHIMOTO Y., UEDA S., FUKAMI K., et al. DNA aptamer raised against advanced glycation end products (AGEs) improves glycemic control and decreases adipocyte size in fructose-fed rats by suppressing AGE-RAGE axis. Horm Metab Res. 2015; 47(4):253-8.

55. LAMAS GA., GOERTZ C., BOINEAU R., MARK DB., ROZEMA T., NAHIN RL., et al. Design of the trial to assess chelation therapy (TACT). Am Heart J. 2012; 163(1):7-12.

56. HONGWEI Y., RUIPING C., YINGYAN F., GUANJUN Z., JIE H., XINGYU L., et al. Effect of Irbesartan on AGEs-RAGE and MMPs systems in rat type 2 diabetes myocardial-fibrosis model. Exp Biol Med. 2019; 244(7):612-20.

57. ZHOU Z., TANG Y., JIN X., CHEN C., LU Y., LIU L., et al. Metformin inhibits advanced glycation end products-induced inflammatory response in murine macrophages partly through AMPK activation and RAGE/NFאB pathway suppression. $\mathrm{J}$ Diabetes Res. 2016; 2016:4847812.

58. GAO H., LI H., LI W., SHEN X., DI, B. Pioglitazone attenuates atherosclerosis in diabetic mice by inhibition of receptor for advanced glycation end-product (RAGE) signaling. Med Sci Mon Int Med J Exp Clin Res. 2017; 23:6121-31.

59. ALTUNINA NV., LIZOGUB VG., BONDARCHUK OM. Alpha-lipoic acid as a means of influence on systemic inflammation in type 2 diabetes mellitus patients with prior myocardial infarction. J Med Life. 2020; 13(1):32-6.

Received $17^{\text {th }}$ June 2020 